\title{
Local Development Model to Increase Moral Behavior
}

\author{
Alif Muarifah \\ Guidance and Counseling Departement \\ Ahmad Dahlan University \\ Yogyakarta, Indonesia \\ alif_muarifah@yahoo.co.id
}

\author{
Dody Hartanto \\ Department of Guidance and Counseling \\ Ahmad Dahlan University \\ Yogyakarta, Indonesia \\ dody.hartanto@bk.uad.ac.id
}

\begin{abstract}
Moral behavior is one essential factors in the development and creation of an advanced and fair society. It is the ideal concept should be acquired and developed. However, at this time, especially teenagers' moral behavior has changed. The changes tend to be on the negative behavior. This article describes moral behavior in the Java community and the importance of moral education. Research carried out with a qualitative approach. The data collection was conducted using a qualitative approach with the method of observation and indepth interviews directly to the source of a lot of information accurately and do focus group and training. This study was conducted at three locations, merelly, an urban area, a rural area and the seashore area in special region of Yogyakarta, Indonesia. The results of this study showed the lack of closeness between the elders and children, and a shift in the role of mother to child and family because of she is busy at work. Today, the emergence of moral behavior in adolescents and children are tended to go to negative behavior such as, apathy, not too concerned with the opinions and public appraisal. The association with fellow teens mostly ignores because of various matters related to ethics. According to the results of observations and interviews were conducted by the researcher, teenagers and children were found in spending lots of time to find satisfaction in the areas of entertainment or amusement. The transfer of education is done without charge ethics and manners.
\end{abstract}

Keywords—Local Development, Moral Behavior

\section{INTRODUCTION}

In the field of moral education, Indonesian people live with rich values from the ancestors. The eastern customs becomes the guideline to behave. The freedom perspective is known as the development of information that causes some people to live out of the cultural values.

The local has a curb, so that their lives out and switch on the outside of equal cultural values, are outwardly and easy to follow. Our society is no longer consider the importance of life inwardly which would bring the value of wisdom and humanism as a civilized nation. The current situation embraces the freedom which has been able to change the life philosophy of humanism to be practical and pragmatic. The quality of the natural environment is decaying and the extinction knowledge adaptation that became the basis of various local communities [1].
Many of the actions that have performed on the human values that should be the foundation of life. The fights between students, homicide, fraud, corruption, manipulation, consumerism, sex, drug use and other deviant behavior have risen so sharply, both qualitatively and quantitatively. [2] Says that moral behavior should be used to foresee one's personality or vice versa. It can also be used as a benchmark for predicting a person which is not civilized. The personality has a dynamic of nature (personality dynamics) that can change according to the age, maturity, learning factors and cultural environment in which the individual resides.

Culture and learning outcomes is an external condition that can color the way of looking and thinking, so it has a picture of himself (self-image) that can shape and influence behavior, including moral behavior. Therefore, moral education can be formal or incidental, both at home and at school [3]. There are two ways to realize the moral education of the philosophical (Kohlberg, 1977) which maximize respect for individual human and universalization [2].

The local culture that is rich in moral values has a principle universality applicable and has been owned by the ancestors of this nation since the first, as has been done by Ki Hajar Dewantoro in education with ethics ing ngarso sung tulodho, ing madyo Mangun Karso, tut wuri Handayani, is a good example in educating, both as a leader as a teacher and as a parent. Principles give an example, at the front, giving a boost amid provide supervision behind a philosophy of educating that has been the core principle of the ancestors in shaping the personality and morality of the nation. Various local wisdom view As can be presented Endraswara them Menang Tanpo Tanding, Kalah Tanpo Ngasorake, Ojo Metani Alane Wong Liya, Catur Ono Mungkur, Mikul Duwur Mendem Jero.

In the midst of his quest for tenderness, thirst for spiritual values, the values of local wisdom and tranquilizers can be conditioning your heart and mind are greedy for power and life hedonism. The noble character of the nation full of oriental ethical norms, respect the dignity of the nation with a personality that andap asor, helpful, humble and refinement is a culture that should be maintained amid the global development of dry-oriented ethics and capitalism. A character that has meaning, mind means of reason, thought or character, while the character is a translation of the thought or 
mean behavior. Manners can be a good character (good character) and an evil nature (bad character) and good manners (good behavior) and bad manners (bad behavior).

This study is intended as an attempt to dig up the cause of the nation's moral Indonesia Economic fade, find a feasible solution through a cultural approach that local values are full of wisdom can be a way of life so as to restore the nation's moral philosophy to a life filled with refinement. To revitalize the old values which will then be used as an alternative to solve the moral problems of the students through learning the local culture that has been eroded by foreign cultures.

\section{METHOD}

The primary source of research data is the result of interviews and focus group discussion were conducted on the subject of ethnic background in Java in Yogyakarta. While the secondary data source in this study is a bibliography of several references (literature review, research, journals, and books that match the theme of the study). The field data obtained through field activity is a source of primary data in units of data analysis and as a basis for decision conclusion. Secondary data sources are used to supplement discussion and analysis processes data. The sources of primary data and secondary data sources used integrative and collaborative.

The research approach used in this study is qualitative. Meanwhile, the emphasis on research methods is ethnomethodology, which belongs to the scientific activities that examine techniques or procedures used by humans to lead them in the various activities of daily life [4]. The qualitative study approach is based on the experience, knowledge, trust informant then recording (recording) and transcribing (transcript) data recorded into the main thing. The data collection process with tools that will become row material from field data [5].

The subjects of this study is Javanese community. The population is the Javanese community with two diverse variants. The variant will distinguish their views of Javanese culture. The closer to the center of Javanese culture, the stronger they adhere to the pillars of the culture. There are three layers of different cultures. The choice of location is based on the representation of community based cultural attributes above. First, the cultural capital of Java (civil servants, gentry, entrepreneurs, teachers / educators and religious leaders) in Yogyakarta Second, the cultural periphery (farmers, workers, rural informal sector) in Kulon Progo, Yogyakarta. Third, the coastal culture (fishermen, employers, workers) at the coast in Bantul.

The data collection used is qualitative approach by using the method of observation and in-depth interviews directly to the source of a lot of information accurately and perform the last focus group discussion and provide training. Qualitative research requires direct observation in the field situation. Educational research will be successful when directly targeted at schools or internalization of values such as family or community. In this study, school and family / community will be the focus of attention in the process of data collection. The strength of such qualitative research; participation observation, interviews and focus group discussions will be applied simultaneously in this study.

The interpretative phenomenological is an approach would be the core of the research on moral education to be done. The interpretative phenomenological approach has some characters, naturalistic inquiry which is the study of natural situations, the survey was conducted on the phenomenon in cases where it is in the context of natural phenomena. The inductive analysis, researchers sought to understand the situation (make sense of the situation) by the situation shown.

\section{RESULT AND DISCUSSION}

The research on the development of local value that improves moral behavior in Yogyakarta province were carried out at three different places. The study was conducted in various settings adjusted to the area where the subjects live in. The study was done by looking at the diverse characters of rural communities (with the majority of farmers work background), the public beach (with a majority background as fishermen and farmers) as well as in urban communities (the majority background as workers).

The character of the rural community (the majority of farmers work background), the public beach (with the background a majority of fishermen and farmers) as well as in urban communities (the majority background as workers) are known to be the non-exclusive community. A community where members residing in it is open to anyone, with notes on urban society which currently has a propensity began individualistic and exclusive.

Based on the researchers determine the background research on three places. The first was as the population in the hamlet Ngentakrejo, District of Kulon Progo Lendah with the background work of farmers. Background The second study is the Regional Sanden Bantul area of Yogyakarta province. Background This second study in the area Ngepet, Srigading Sanden. Located on the road Samas sub-district in the area of Sanden. The village is known as a village adjacent to the beach. Background The third study is a sub-district Pandeyan Umbulharjo village. In this third background, research background is in a residential complex that in fact, many immigrants encounter (not native of ethnic Javanese).

\section{A. Moral Behavior Growing In Children and Adolescents}

The first results were obtained from the interview is about the experience of the subject regarding good behavior change at this time. According to the current issue of children's physical appearance is very striking different. It can be seen from the dress code that is far from the standards set by the society. The type of clothing chosen by children and teenagers today tend to be the choice of transparent, less material, and look sloppy (impressed at will and showing things that are eccentric or strange and disregard of propriety which is still preserved by the people. This is by the exposure [6] presents 
the results of literature review bringing about oral cognition and moral action.

The intercourse with friends that is teenagers and children are currently running with no regard to matters related to ethics, including greeting each other with those calls are not suitable as "Nyet", "Nyuk" and also "Su" (the call derived from animal designations). But already becoming the norm and have forgotten the things that have become a good habit in greeting. The subject also considers promiscuity among adolescents has undergone many shifts.

The researcher then dig up information about his knowledge of the relationship with other people around. When interacting with the people around him in the eyes of the subject of research known that no longer occur kesopanan 13 ethics. It is no longer among them with custom greetings, respect for older people. This is evident when interacting young children currently in the spoken word, and act considered to be far from existing Keadaa first. Regarding interacting with the opposite sex of children and adolescents currently looks more daring of them raised in behavior when tandem with two-wheeled vehicles, as well as visit.

According to the results of observations and interviews conducted at this time teenagers and children were found in the use of more time spent searching for satisfaction with chatting or shopping. The teenagers and children today love entertainment or amusement.

Teens and children today prefer to be apathy, not too concerned with the opinions and public appraisal. Another perspective on the Jones opinion was explaining the reasons for the award given exclusively to children and young people, in this case, the opposite sex. As revealed in a study conducted by Tolor, Kelly, Stebbins ${ }^{5}$ states that the attitudes of self and acceptance of others are stronger among women than men. Other data obtained in Sanden be interesting to note because it emphasizes on the dysfunction of the role of the mother, which the mother now felt less in assisting their children due to work to help her husband in hari14 meet their daily needs.

The data were obtained through focus group activities are the same thing and can be drawn an outline. Among them is the comparison made at the school are: division picket clean the school, carrying a bag ladies and teachers already entrenched, if now be submitted to the school's janitor, according to the subject in Sanden cultivate picket together to clean the actual class needs to be done in an effort to educate the children can interact each other, working in groups, and understand the work of, for example, if the home requested help for children doing homework bygone era immediately working without being asked for help, but children today no longer want to do homework. This further reinforces the importance of moral education in today's society.

Through focus group discussion results can also be known to begin the abandonment of traditional games that require creative power and high social interaction is now beginning to none. This tends to encourage individuals to become individualistic. And ultimately encourage moral behavior are less positive.

\section{B. Independence and Dependence}

The problem of moral behavior cannot be separated from the problem of independence and dependence of a person. It arises as a result of their expectations and judgments that do to ourselves. As revealed by Witkin that the court independence and dependence also shows a connection with the concept of self and moral behavior. Still according to Witkin people with dependency tend to be passive, obedient, and low in feelings towards her pride. In contrast with that of people with independence tend to be independent, lacking a sense of anxiety and feelings of high self-esteem.

\section{CONCLUSION AND RECOMMENDATION}

Moral behavior is one important factor in the development and creation of advanced asyarakat and fair. It is the ideal concept should be acquired and developed. However, at this time, especially teenagers moral behavior has changed. The change this time tends to be on the negative. This is evidenced by the results of this study. The results of this study include the lack of closeness between parents and children, and a shift in the role of mother to child and family because of busy work that focused on the situation. The emergence of moral behavior in adolescents and children today are more tended to options for apathy, not too concerned with the opinions and public appraisal. Another perspective on the Jones opinion was explaining the reasons for the award given exclusively to children and young people, in this case, the opposite sex. Children's physical appearance is very remarkable different. It can be seen from the dress code that is far from the standards set by society. The type of clothing chosen by children and teenagers today tend to be the choice of transparent, less material, and look sloppy (impressed at will and showing things that are "eccentric" or strange and disregard of propriety which is still preserved by the public.

The association with fellow teens and children is currently running with no regard to matters related to ethics, among others greet with calls that do not fit or when interacting with people around them unfounded according to survey results revealed that no longer occur courtesy. It is among no longer exchanged what habits, respecting elders. This is an evident when interacting young children currently in the spoken word, and acted already far away from the existing situation first.

Through the research results can also be known to begin the abandonment of traditional games that require creative power and high social interaction is now beginning to none. This tends to encourage individuals to become individualistic. And ultimately encourage moral behavior are less positive. The problem of moral behavior cannot be separated from the problem of independence and dependence of a person. 


\section{ACKNOWLEDGMENT}

This study is the result of the first year of research grants from Competitive Grants scheme. This research is aimed at developing the local value to improve moral behavior in Yogyakarta.

\section{REFERENCES}

[1] Ahimsa-Putra, H.S. 2008. Ilmuwan Budaya dan Revitalisasi Kearifan Lokal, tantangan teoritis dan metodologis. Pidato Dies Natalis ke- 62 Fakultas Ilmu Budaya UGM.

[2] Bear.G G and Richard, HC, 1981. Moral Reasoning and Conduct Problem in the Classroom. Journal of Education, 73 (5): 644-670

[3] Sardjono, MA.1995. Paham Jawa, Menguak Falsafah Hidup Manusia Jawa, Lewat Karya Fiksi Mutakhir Indonesia, Pustaka Sinar Harapan, Jakarta

[4] Coulon, A.. 2004. Etnometodolohi (terjemahan Jimmy Ph. Paat). Mataram: Yayasan lengge. Endraswara, S.. 2003. Budi Pekerti dalam Budaya Jawa. Yogyakarta: Hanindita.
[5] Silverman, D. 2006. Qualitative Research, Theory, Method and Practice. London: Sage Pub.

[6] Blasi, A, 1980. Bringing Moral Cognition and Moral action: A Critical Review of the Literature, Psychological Bulletin, 88 (1): 1-45

[7] Frankena, WK, 1971. Moral Education, Philosophic View

[8] Geertz, H, 1983. Keluarga Jawa. Grafiti pers. Jakarta

[9] Gordon, T., Holland, J., and Lahelma, E. 2001. "Ethnographic Research in Educational Setting" dalam Atkinson, et.al (eds.) Handbook of Ethnography. London: Sage Publication.

[10] Irwanto. 2006. Focus Group Discussion. Jakarta: Buku Obor.

[11] Kirby, P. 2006. Vulnerability and Violence, the Impact of Globalization. London: Pluto Press.

[12] Lee, LC. 1971, The Concomittant Development of Cognitive and Moral Modes of Thought: A test of slection education from Piagets Theory. Genetic Psychology Monographs, Human Development and Family Student. Cornwll University, 83, 93, 146

[13] Lewellen, T.C. 2002. The Anthropology of Globalization. Westport: Bergin\&Garvey.

[14] Liamputtong, P., Ezzy, D. 2005. Qualitative Research Method. Oxford: Oxford University press. 